\title{
Actor-networks and the diffusion of management accounting innovations:
}

\author{
A comparative study \\ Simon Alcouffe ${ }^{\text {a,1 }}$, Nicolas Berland ${ }^{\text {b }}$, Yves Levant ${ }^{\text {c }}$ \\ ${ }^{a}$ EM Lyon Business School, 23 avenue Guy de Collongue, 69134 Ecully Cedex, France \\ ${ }^{\mathrm{b}}$ Paris Dauphine University / CREFIGE (Associate Researcher), place du Maréchal de Lattre \\ de Tassigny, 75775 Paris Cedex 16, France \\ ${ }^{\mathrm{c}}$ Lille University of Sciences and Technologies, GREMCO LEM (UMR CNRS 8179) / Lille \\ Graduate School of Management, ISFEM, 104, avenue du Peuple Belge, 59043 Lille Cedex,
} France

\begin{abstract}
This research is concerned with the diffusion of management accounting innovations viewed as a process of actor-network building and translation. The aim is to better understand the nature of accounting change. Using Actor-Network Theory (ANT), we analyze two innovations that have had different fates in France. These innovations are the Georges Perrin method (GPM) and Activity-Based Costing (ABC). We are particularly concerned with the dynamic of actor-networks throughout the diffusion processes of these innovations. We show how problematization, interessement, enrolment and mobilization take many, and often very surprising, forms for diffusion to occur.
\end{abstract}

Keywords: Innovation; Actor-Network Theory; Diffusion; Translation; ABC; GP method.

\footnotetext{
${ }^{1}$ Corresponding author. EM Lyon Business School, Dpt. of Finance, Economics and Control, 23 avenue Guy de Collongue, 69134 Ecully Cedex, France, Tel.: +33-4-7218-4635; Fax: +33-4-7833-7928.

E-mail addresses: alcouffe@em-lyon.com (S. Alcouffe), nberland@free.fr (N. Berland), yves.levant@univlille1.fr (Y. Levant).
} 


\section{Introduction}

A large proportion of managerial and scientific publications deal with the diffusion of innovation (Rogers, 1995). According to Wolfe (1994), organizational innovation research can be classified into three distinct streams. Diffusion of innovation tries to determine the innovation's diffusion curve over time and to identify the factors explaining its shape. Organizational innovativeness is concerned with what makes an organization innovative. Process theory deals with the stages through which an organization passes during the innovation's implementation process. This article pertains to the diffusion of innovation research. It addresses questions such as: How can we understand the difference in diffusion of management accounting innovations? How can we distinguish success from failure? Do the explanations for diffusion balance those for non-diffusion?

A large number of studies with a positivist and determinist approach are concerned with the diffusion of innovation. However, the concepts and frameworks used by most of this type of research are not easily transposed to the study of managerial innovations (Lundblad, 2003). Moreover, positivist research in management (accounting) often chooses to ignore power struggles, as well as rationalities other than technical ones, which are likely to greatly influence the diffusion of new practices (Baxter and Chua, 2003). These limits lead us towards alternative research in management accounting.

Baxter and Chua (2003) identify seven different research perspectives that lie outside the main stream. This article follows the line of "Latourian" research". This stream of research is concerned with the fabrication of management accounting technologies through the following of actor-networks. Unforeseeable interactions between human and non-human actors are central to this type of analysis. In this view, accounting innovations diffuse because they translate the changing and transitory interests of various groups of actors who are looking to

\footnotetext{
${ }^{2}$ In this paper, we will systematically refer to "Actor-Network Theory" rather than "Latourian research". This is to stay consistent with this stream that claims it is inappropriate to assign a hero (Bruno Latour) to a collective process. We are grateful to one of the reviewers for suggesting this.
} 
maintain their position and influence within organizations and society. Actors use accounting innovations to manufacture "inscriptions" (i.e. figures and numbers which become "facts", see Robson, 1992) and manipulate them to serve their interests.

Following Actor-Network Theory (ANT), we take as an axiom that an innovation's technical characteristics are not sufficient to explain the "success" or "failure" of its diffusion (Latour, 1987, p. 258). Moreover, the notions of success and failure are problematic within this epistemological stance. Within the diffusion process, we are particularly concerned with the dynamic and interactions of actor-networks, i.e. the arguments network members decide (or not) to use to promote the innovation and successfully interest and enroll other actors. The diffusion of the Georges Perrin Method (GPM) and Activity-Based Costing (ABC) in France provide two illustrative stories for comparison.

The remainder of this article is organized as follows. Section 2 presents the main concepts of ANT and sets out a review of management accounting research using this framework.

Sections 3 and 4 describe the dynamic of actor-networks in the diffusion of GPM and ABC. A discussion of these two stories follows in Section 5.

\section{ANT and the Diffusion of Management Accounting Innovations}

This research paper is conceptually grounded on ANT (Callon, 1986; Latour, 1999; Law and Hassard, 1999). ANT has specific benefits for the study of accounting change in general and management accounting innovation diffusion in particular (Chua, 1995) ${ }^{3}$.

First, accounting change has widely been studied but with little attention paid to the change process in itself (Hopwood, 1987). Moreover, as Briers and Chua (2001) note, a majority of studies do not acknowledge the uncertain nature of accounting change outcomes

\footnotetext{
${ }^{3}$ Strictly speaking, we could distinguish "diffusion" from "translation" as they often refer to two separate epistemological stances (Quattrone, 2005). The latter implies a pluralistic perspective of evolution taking into account the role of technologies and human and non-human actors in the co-production of innovations whereas the former rests on a very specific and autonomous ontology of an immutable object. In this paper, we use the terms "diffusion" and "translation" indifferently, diffusion being used as a synonym of translation in a broader sense.
} 
as these studies take place ex-post. In accordance with ANT, we propose to study accounting change in a non-linear fashion in which "the success/failure of a machine or technology cannot be predicted with a list of social factors" (Briers and Chua, 2001, p. 240). Success and failure are rather social accomplishments of many different human and non-human actors that lie in the hands of those who come after the innovation's "inventor" (Latour, 1987, p. 259).

Second, ANT leads us to compare in a number of ways the construction of accounting innovations with scientific controversies, thus acknowledging power struggles. Accounting technologies are not considered as inert: they have to be pushed and pulled by actors in order to diffuse. Hence, the assumption that innovations are rationally accepted because they accurately represent reality and are technically more efficient is questioned (Latour, 1996).

Third, by embracing ANT's conceptual framework we hope to avoid a number of limits that characterize previous research on (management accounting) innovation diffusion, such as means-end reasoning or the lack of attention paid to the ways in which accounting reality is constructed as well as the role power struggles play in this construction (Baxter and Chua, 2003, p. 102-105).

\subsection{ANT as a sociology of translation}

ANT explains innovation diffusion through a process called "translation" (Callon, 1986; Latour, 1987). This process analyzes the innovation within the context in which it evolves. Context is considered as a constituent element of innovation rather than a source of explanation. It is not a separate element of innovation and it does not determine innovation unilaterally as if people were embedded in an "iron cage" (DiMaggio and Powell, 1983; Latour, 2005, p. 191-217). Context is inseparable from localized management actions and interactions within actor-networks. Both have to be analyzed simultaneously. In this view, change is embedded in the confluence of various organizational and extra-organizational factors (Briers and Chua, 2001, p. 239). 
ANT sees the "success" of any innovation as a paradox. This success depends on many actors other than its pioneers - usually the users - and on their expectations, on their interests and on the problems facing them (Lowe, 2001b). The translation process underlines the existence of a cluster of links that bind the innovation with all those who use it. Pioneers must recruit allies to participate in producing the innovation but pioneers also have to control allies' acts and gestures to make their actions foreseeable (Lowe, 2000). The problem is that if allies are recruited, they might transform the innovation into something completely new and different. Controlling them will thus be more difficult. Hence, adopting an innovation implies adapting it and this adaptation is the result of a collective construction effort (Preston et al., 1992). Therefore, ANT regards the development of any innovation more like a complex process with multiple, cumulative and conjunctive progressions of convergent, parallel and divergent activities rather than a linear, sequential model ${ }^{4}$.

The process of translating an innovation implies that interactions are created between actors who make alliances in order to pursue some goals rather than others in the change process (Chua, 1995). These alliances form "actor-networks" made of both human and nonhuman actors (such as technical artifacts). Non-human allies are given a voice through "spokespersons" who contribute to the building of the network. Networks become stronger and stronger as they incorporate human and non-human allies. In the end, this construction is successful if sciences and technologies, or in our case accounting innovations, acquire a solid and sound appearance, i.e. they become "black boxes" which will not subsequently be questioned for at least some time (Latour and Woolgar, 1979, p. 241-243).

Translation involves four processes that are intertwined and interact with each other. These are "problematization", "interessement", "enrolment” and "mobilization" (Callon,

\footnotetext{
${ }^{4}$ Sequential models picture the development of an innovation as a linear process consisting in a sequence of separate stages such as "research", "development", "commercialization” and so on (see Rogers, 1995, p. 133). Latour (1987, p. 132) argues that such models separate technology and science from society and, hence, are of little help in understanding the success or failure of innovations.
} 
1986). Problematization refers to actors' efforts to convince others to subscribe to their own view by showing they have the correct solutions. Problematization calls on external elements such as cultural and discursive resources (Ezzamel, 1994). Interessement corresponds to the construction of the interface between the interests of the various stakeholders and to the strengthening of links between these various interests (Lowe, 1997). Interessement is successful thanks to allies and spokespeople who reproduce the whole of society in miniature and speak for the non-humans (Lowe, 2001a). Enrolment is the creation of alliance networks, the aim of which is to build up agreement among the stakeholders concerning their interests. Finally, mobilization refers to the monitoring of the various interests so that they remain more or less stable (Mouritsen et al., 2001).

Besides these four processes, "trials of strength" can take place at anytime (Latour, 1987, p. 74). To be victorious, system builders must fight against "counteractors" and defeat their “anti-programs" (i.e. competing innovations). Battles can take place on five fronts: with other members of the network, with competing networks, with clients, with non-human actors, and with powerful economic forces (Jones and Dugdale, 2002). During these battles, the innovation is modified/adapted in response to trials. Trials consist in questions being asked by counteractors that help develop the innovation in a more acceptable way. In the end, the translation process works if the actor-network supporting the innovation represents, in all its richness, complexity and diversity of interests, society as a whole, in such a way that the solution made acceptable (through trials of strength) to the former will also be acceptable to the latter (Latour, 1987).

\subsection{ANT in management accounting research}

Recently, Baxter and Chua (2003) extensively discussed the contribution of ANT to management accounting research. As a result, we will not discuss it again here. The question, 
however, remains - how does this paper compare to previous research and how does it contribute new knowledge?

ANT has been used in management accounting research to address two questions. First, what are the roles played by accounting innovations within organizations and society once they have reached the status of black boxes? In this respect, ANT-based research is particularly concerned with the way accounting technologies are able, once created, to "act at a distance" thanks notably to the inscriptions (i.e. accounting figures) they manufacture (Bloomfield and Vurdubakis, 1997; Ogden, 1997; Robson, 1994). Second, how are management accounting innovations produced, modified and accepted (Chua, 1995; Preston et al., 1992; Quattrone and Hopper, 2005)? For example, Jones and Dugdale (2002) explore the rise of $\mathrm{ABC}$ in the USA as a socio-technical expert system that is formed mutually with the construction of the actor-networks that create it.

This article addresses the second question. The aim is to understand how and why such accounting innovations as GPM and ABC were created and/or modified and then eventually became accepted in France. To do this, we will apply the ANT concept of translation. In doing so, we will discuss the notion of accounting change and the innovating nature of such techniques as GPM and $\mathrm{ABC}$. We will also attempt to show how accounting innovations do not operate in a vacuum but instead, are in competition with one another. Problematization arguments are scarce resources for the enrolment of which rival programs compete. We will also discuss the nature and role of interessement modalities and question the idea that commercial interessement may be the only driver of our global society. Finally, we will focus on the success/failure dichotomy and the issue of increased homogenization of accounting practices through the diffusion of such innovations as $\mathrm{ABC}$.

In comparison with previous ANT-based management accounting studies, our research may be distinguished in terms of its level of analysis and its comparative nature. Most 
research addressing the development issue of accounting innovations do so at a "local" (i.e. organizational) level and study only one innovation at a time. This research contributes new knowledge since it is one of the first (along with Jones and Dugdale, 2002) to take a more "global" level of analysis and to study more than one innovation at a times.

\subsection{About our two stories}

Writing an overly detailed method section would be a paradox within the socialconstructivist paradigm to which this paper belongs. Indeed, "why do we need a methodological section if how something happens is reciprocally linked to why it happens?" (Quattrone, 2004, p. 240). As Quattrone points it, the research method section of a paper is not a neutral tool: it reinforces the idea that there exists a dichotomy between the research object and its analysis. Hence, we only provide here details about the selection of our "case studies" and about our sources of "data".

Through the multi-faceted stories of GPM and ABC diffusion in France, we compare the fabrication process and the translation mechanisms of management accounting innovations operated by different actor-networks in interaction. Each case is specific: the fate of an innovation depends on unpredictable interactions between actors who participate in everevolving networks and are tied together. However, in comparing our two stories, we treat "winners" and "losers" symmetrically (Bloor, 1976). Moreover, as we look at the interactions of GPM and ABC with the same non-human actors as other innovations of their time, we may transform our understanding of the success/failure of accounting technologies. Hence, conclusions drawn from this comparative study may enrich our comprehension of accounting change (Chua, 1995, p. 116).

\footnotetext{
${ }^{5}$ By using the term "global level of analysis", we mean that our study does not focus specifically on the diffusion of management accounting innovations within the "local" settings of one or a few organizations. We do not seek to open the micro/macro debate or to address the actor/system quandary (Latour, 2005, p. 169).
} 
We selected GPM and ABC for three reasons. First, both innovations belong to the same field: management accounting. Second, their diffusion occurred in a continuous framework in terms of space (France) and time (from 1950 to 2000). Both human and non-human actors participated in the diffusion of both innovations. Third, as they have experienced different fates in France, our comparing GPM with ABC enables a symmetrical analysis of their success/failure ${ }^{6}$.

Data were collected from various sources. For both innovations, we relied on a detailed examination of documents from the periods. These documents came from various sources: company archives, interviews, reviews, books, case studies, etc. For GPM, we conducted an in-depth interview with the son of its inventor, Georges Perrin. We also consulted the archives of La Méthode GP consulting firm and the Ecole Centrale de Paris ${ }^{7}$. Concerning ABC, we gathered data by examining French professional and academic journals and conducting 25 interviews with key actors of the diffusion process (academics, consultants, software publishers, end-users).

We then organized and analyzed the data in an inductive way, sensitized by the theoretical constructs of ANT. We drafted a general story of the diffusion of each innovation following the actors and their inscriptions. Following the ANT argument about the unnecessary separation between description and explanation (Latour, 1991, p. 129), we deliberately constructed these stories as two theorized accounts. This strategy, similar to Briers and Chua (2001), enabled us to avoid distinction between "description" and "explanation", although a series of reflective comments on the comparison of the two cases follows in Section 5.

One limit of this paper is its unwillingness to claim to be objective and to reflect any reality other than that of its authors. The two stories we develop hereafter do not constitute an asubjective, independent write-up of "results". These stories could have started at other points

\footnotetext{
${ }^{6}$ In his description of Aramis' failure in Paris, Latour (1996) draws this type of symmetrical analysis with a similar transportation project that succeeded in Lille.

${ }^{7}$ The Ecole Centrale is a famous French engineering school in the Grandes Ecoles tradition.
} 
in time and space, had the authors read other materials or had they wanted to compare GPM and $\mathrm{ABC}$ with other innovations, for instance.

\section{The Diffusion of GPM in France}

Georges Perrin (1891-1958) was a typical example of the Schumpeterian innovator. Lending an ear to his market, he was convinced from the moment World War Two ended that a need in the field of cost calculation could be met using a new method: the "GP" method (GPM), immodestly coined from his own initials.

\subsection{Georges Perrin's initial efforts to problematize GPM}

Georges Perrin was not just another engineer. His sound technical credibility was grounded on his training as well as on his long professional experience. He graduated as an engineer from the Ecole Centrale de Paris, one of France's most famous engineering schools. From 1920 until the eve of World War Two, he worked in the field spending all his professional life in the textile and engineering industries. As an engineer with managerial responsibilities, he was regularly faced with the problem of indirect cost allocation. His personality precluded any controversy surrounding his invention, which, from his point of view, was to be adopted without adaptation.

For the design of his method, Georges Perrin set out from the idea that it was difficult to measure factory output using a single common unit. This difficulty meant that it was impossible to allocate overheads "correctly" to each line of manufactured goods. Rather than looking for the best possible breakdown of costs, it was possible to shift the emphasis onto a standard through which the unification of production could be obtained. Whatever the mix of products manufactured, the goal was to use a common unit of measurement called the "GP". Choosing it was arbitrary; it could correspond either to a specific machine or to a specific part that would be called a "basic item". 
The logic was the following: In a factory, each work operation has a time constant that can be calculated in GP units. It is possible to calculate the number of GP units necessary to manufacture each article if the working times for each operation are known. Then, the whole factory output can be calculated in GP units over a given period. The production cost associated with a GP unit can then be computed: it is equal to the firm's expenses and running costs over the period divided by the number of products, measured in terms of GP equivalents, produced during the same period.

Georges Perrin was convinced that, in and of itself, his method would be of interest to other actors, without understanding that he had to construct this interessement. Indeed, from Perrin's point of view, this interessement could only be linked to such exogenous factors as the necessity to improve productivity, the liberalization of prices, and the increase in competition due to the rebuilding of Europe. Perrin was an engineer with a rational and Cartesian mindset. For him, an innovation with intrinsic qualities was bound to meet with success. No controversy was planned for, because that would have been a waste of time. Hence, he intended to use what he thought was a context favorable to the development of new management tools to diffuse his method, without imagining that the context could be a collective construct.

Stimulated by the Marshall Plan, France was undergoing reconstruction (Ellwood, 1992). It was preparing to enter the Common Market at a time of unprecedented economic growth. The goal was to restore commercial market laws encouraging companies to set their prices freely. With the help of the USA, French society wanted to modernize itself to restore its national power. The Association Française pour l'Accroissement de la Productivité organized productivity missions to the USA ${ }^{8}$. The missionaries returned with unexpected ideas resulting from a translation performed during their trips. Having left France convinced that its

\footnotetext{
${ }^{8}$ The role of this association was to oversee the diffusion of knowledge or information and the coordination of all institutions and organizations involved in the productivity effort. The productivity missions were a consequence of the Marshall plan that enabled thousands of civil servants, executives, managers and unionists to discover the methods of manufacturing and organization in American companies.
} 
economic lag was due to a technological gap, missionaries subsequently translated this diagnosis into a problem of modes of management (OECCA, 1952). Hence, actors seemed ready to be interested in ideas such as GPM. Perrin also intended to ride the wave of the creation of a real French management industry with the multiplication of non-human actors such as think tanks, seminars and training sessions aimed at executives (Boltanski, 1982).

\subsection{The uncertain nature of success and failure}

Like any cautious innovator, Georges Perrin wished to protect his discovery. He saw himself as the inventor of a method he wanted to promote but, at the same time, he feared disclosing his "secrets" since he could not patent them. Hence, Perrin did not diffuse all the technical aspects of his method and even banned any diffusion of it - beyond the intervention of his consulting firm - by protecting the trademark "GPM" (Perrin, 1951). He thus prevented any adaptation and translation of his idea. Unfortunately, he protected his innovation so well that its confidential and secret nature also resulted in its confidential and restricted diffusion.

Today, one must admit that GPM has had only a "limited success". An analysis of the various documents available reveals that only between 150 and 200 implementations were made. Over time, GPM has almost sunk into oblivion, even though a few inscriptions of it can be found in several French textbooks (Lauzel and Bouquin, 1988). Like many other innovators, Georges Perrin therefore overestimated the innovating and interest-generating potential of his innovation and failed to interest other potential allies. Is that the ending of a story of failure? Far from it!

In France, GPM was rediscovered in the 1990s following the controversy surrounding traditional costing methods led by $\mathrm{ABC}$ proponents. For strategic reasons, leaning on the arguments of Johnson and Kaplan (1987), the managers of a consulting firm decided to restart the diffusion of GPM, first under the name of "UP method" in 1977 and then "UVA method" from 1995 onwards. A controversy began to develop between the consulting firm and 
academics (Levant and de La Villarmois, 2001, 2003; Mévellec, 2002). However, sheltered by its patents, the consulting firm prevented any adaptation of the method, going as far as labeling "best practices". In the final analysis, this method has struggled to find resonance beyond this early network. Yet, the new surge of interest stresses the practical applicability of Georges Perrin's method. In France, he was one of the first to highlight the weaknesses of full costing methods such as the Sections Homogènes that were then the reference in the field of cost accounting (Lebas, 1994a). Indeed, Perrin's (1962, p. 12) criticisms in the 1950s were very close to those of $\mathrm{ABC}$ advocates in the 1980s:

"The application of this flat percentage could be admitted up to a point... But from the moment that mechanization resulted in an increase in overheads and took them up to proportions of $500,800,1000 \%$, which is frequent nowadays, cost prices worked out on the too narrow basis of just the productive labor force, and therefore burdening by the same percentage of overheads the hand-made article and that which requires the use of expensive machine-tools, cannot be considered as valid any more."

It must also be noted that although GPM has not diffused in France, this has not prevented it from being translated across borders, spreading to the UK (Rodrigues and Brady, 1992) and Brazil under the name of "UPE" (Levant and de La Villarmois, 2004). Also, more recently in the USA, a fairly similar method seems to have been used by Boeing (Dhavale, 1996). So why has GPM not experienced greater success in France? It seems that Perrin's failure did not stem from his idea in itself, as witnessed by its diffusion in other countries and by its recent revival in France. By designing a uniquely technical innovation, Perrin was not able to interest other actors who could have been powerful allies in supporting the method. Holding to the purity of his method, he equally prevented any attempts at adaptation and translation. 


\subsection{Commercial arguments as the only interessement device}

In 1947, Georges Perrin found himself isolated. Perrin had spent his entire professional career as a manager of regional companies in the East of France and Brazil, therefore far from Paris. He was totally unknown and not part of the "aristocracy" of the French business world (Kipping, 1999). At this stage, one may criticize Georges Perrin for only behaving like a good technician, relying solely on the technical qualities of GPM to diffuse it. This would easily explain his failure. The problem is that he did try to enroll allies, but was to rely solely on commercial modes of interessement.

Indeed, Perrin rapidly became aware that he could not start up on his own. So, he persuaded Yves de La Villeguérin, the manager of Fiducia - a network of chartered accountant firms - to associate with his project. The interessement of Fiducia in GPM stemmed from its desire to diversify its activities. Having only chartered accountancy and audit activities, Fiducia sought to diversify by proposing a simple cost accounting method. However, Fiducia's clientele did not rush to try out GPM. Perrin attributed this to Fiducia's reluctance to diffuse his method whereas Fiducia questioned the level of know-how of Perrin's staff and stressed the technical difficulties they encountered. Once again, the diagnostic remained centered on technical aspects whereas the network of allies lacked consistency for want of modes of interessement that had sufficiently power outside the PerrinFiducia duo.

One possible explanation for this misunderstanding is the difficulty of generating the interest of accountants in a method designed by - and for - engineers. Indeed, the implementation of GPM was the province of men experienced and trained in the methods of industrial organization, a technique not mastered by accountants. It was easier for Georges Perrin to interest managers of industrial companies with scientific training than to interest financial managers or accountants. Such an absence of adaptation that would translate 
accountants' interests was undoubtedly harmful to GPM's diffusion. In its original form, GPM associated very imperfectly two social worlds with different languages and techniques. Thus, quite often, accountants were against its adoption because they feared it would deprive them of their control over cost accounting.

In 1950, a controversy over the modes of commercial interessement broke out between Georges Perrin and Fiducia that led to the creation of La Méthode GP Corporation. The outcome of this development was Perrin's loss of control over the company in charge of marketing his innovation. This moment in GPM history is quite interesting since it was one of the rare occasions that Georges Perrin agreed to compromise on his initial idea. But this opportunity for adaptation concerned the company in charge of diffusion, and not the method itself. Perrin also attempted to broaden his network by inducing new modes of interessement in GPM through the publication of numerous inscriptions in trade magazines ( 9 between 1953 and 1955).

From 1950 to 1958, Perrin did not succeed in enrolling many allies. Besides the Fiducia and subsequently La Méthode GP consulting firms, Perrin also sought potential allies among employers' associations. Documents from La Méthode GP consulting firm reveal that tentative enrolments were made with employers' associations in order to implement $\mathrm{GPM}^{9}$, but still without allowing any adaptation of the method. These contacts sometimes resulted in GPM presentations or trials in factories through spokespersons. Unfortunately, none of these resulted in the general use of the method by all the members of any one employers' association. Worse still, some associations criticized GPM to their members, behaving like counteractors $^{10}$. In parallel, Georges Perrin tried to enroll other actors that were already enrolled in networks supporting competing methods (see §3.5. below) who did not join him.

\footnotetext{
${ }^{9}$ Such links arose with the following associations/confederations: hoisting and serial handling machine manufacturers, electrical wire and cable makers, telephone and telegraph companies, electrical material manufacturers, cotton makers of western and eastern France, the iron and steel industry, and manufacturers of textile machine-tools.

${ }^{10}$ For example, the cotton makers of eastern France seem to denigrate GPM to its members (Georges Perrin personal archives).
} 


\subsection{The quest for allies continued...}

On February 5th, 1958, Georges Perrin died. This event could have provided an opportunity to depersonalize and adapt the method. On the contrary, Suzanne Perrin and the son of Jean de la Villeguérin - acting as "testamentary executors" - took it up unchanged. The possibility of a translation involving new allies did not become reality. From 1958 to 1963 , Suzanne Perrin simply continued her husband's publishing inscriptions under her name (10 articles between 1959 and 1967). These new inscriptions reflected a total absence of translation of the method and were only rewritings of former versions. Also, not having found any new allies, Suzanne Perrin invented some, writing under the pseudonym of Xavier Serrières (Serrières, 1969). During this period, the company La Méthode GP earned its living more from updates than from attracting new clients. Similar to the beginning of this story, commercial interessement remained the sole mode implemented.

A few years later, Suzanne Perrin again tried to enroll new allies, but always maintained only commercial modes of interessement. She granted exclusive rights for the use of GPM to the Institut d'Etudes et de Mesure de Productivité (IEMP) in return for royalties. The latter expected to finance the incorporation of GPM into the computer-assisted management programs that it was developing. It was indeed during this period already a weakness for a cost accounting method not to be incorporated into powerful computer-aided means of calculation. If IEMP embodied GPM in software, the enrolment of this new non-human actor would greatly contribute to its translation and its adaptation. Unfortunately, a commercial controversy between Suzanne Perrin and IEMP rapidly arose leaving GPM short of a software ally. In 1971, La Méthode GP consulting firm terminated its agreement with IEMP and signed other agreements with various consulting firms (Maynard France, PROSCOP, Les Ingénieurs Associés, Ouroumoff et Associés). But none of these commercial agreements lasted long, since 
the contracts specified that the mandated companies were not allowed to make any changes to GPM without Suzanne Perrin's agreement, which she never gave.

Georges Perrin and his successors therefore tried to enroll allies and spokespersons but in vain. He and his wife exhausted them one after the other. Suzanne had the opportunity to embody the method into a computer program, something that in those days would undoubtedly have contributed a lot of power to the network, but she failed to do so. Moreover, the Perrins remained adamant about the GPM's "technical purity". The name of the method, in itself, showed an excessive desire to claim a place in History. Playing the role of the "guardian of the temple", Suzanne successively angered all the consultants to whom she licensed the method by refusing any transformation. This made the network rather unstable due to the frequent disputes that opposed her to the consultants. Also, this inhibited any translation by other potential allies by preventing them from recapturing the concept for their own purposes.

To sum up the Perrins' point of view, they made alliances with incompetent and/or ignorant people. However, the story is more complex: Georges had managed to persuade an important chartered accounting and auditing firm of his day: Fiducia. In spite of their differences, the managers of this firm believed in the method, which accounts for the longevity of their support. After the first dispute, Fiducia became even more involved and remained in the operation after Georges Perrin's death. However, the potential users did not follow. However, the network supporting GPM did not expand because the Perrins also had to face anti-programs supported by powerful networks of counteractors...

\subsection{Absence of any controversies with anti-programs}

While trying to diffuse his method, Georges Perrin had to fight against two anti-programs that appeared at the same period: one French, the Sections Homogènes, and the other American, Direct Costing. The Sections Homogènes method was developed throughout the 
1930s in France (Lemarchand, 2002) and was finally inscribed in the 1947 French general chart of accounts (Plan Comptable), which gave it official status. It therefore became the reference method in terms of full costing in France, supported by a strong and heterogeneous network of human and non-human actors. It was notably widely diffused by the accountants' profession and taught in all universities, thus training generations of accountants to speak the same language (Standish, 1990).

When the Sections Homogènes were inscribed in the Plan Comptable in 1947, any reference to the system of values that had supported its development was erased through collective amnesia. These values were those of corporatism and of technocratic and economic planning ideas (Berland and Boyns, 2002; Kuisel, 1981). This anti-program was starting to achieve the status of black box when Georges Perrin attempted to launch his own method by using the very same arguments of problematization. Perrin thus faced the Sections Homogènes using arguments that are now disgraced and were deliberately forgotten when the latter method became a black box. Equally, Perrin's ideas did not change and were even perpetuated in his posthumous book in which a whole chapter deals with "labor union potential, industrial agreements and banking regulation” (Perrin, 1962).

Besides the Sections Homogènes, Georges Perrin had to face the development of Direct Costing, a new management accounting technique brought back from the USA by the network of the productivity missions. Considered as a model of excellence after 1945, US management methods were diffused in Europe on a large scale in the 1950s (Kipping and Bjarnar, 1998). This translation stemmed from a shared will driven by a small elite constituting the Commissariat Général au Plan (Djelic, 1998) ${ }^{11}$. It also coincided with a drop in anti-USA feeling, if not with a fascination for this country that translated into the importation of its system of values (Ellwood, 1992). On the operational level, US management techniques were widely translated by another network of powerful actors composed of training organizations

\footnotetext{
11 The French planning board was created in 1946 and was modeled on the American War Production Board.
} 
for executives and consultants (Kipping and Bjarnar, 1998). Well aware of this trend towards “Americanization", Perrin (1955) himself tried to lean on the modernity US managers embody to diffuse his innovation:

"The American experts of the Westinghouse Corporation, who come each year to control their Parisian subsidiary that manufactures brakes, think that GPM, in their opinion, is superior to everything that they have currently in America in the field."

However, Georges Perrin and his successors never had the opportunity to take part in controversies, battles or struggles with the Sections Homogènes and Direct Costing antiprograms. For instance, only very rarely did Perrin criticize these rival innovations in his public writings. Faced with this absence of aggression, the networks supporting the Sections Homogènes and Direct Costing, in return, did not even show the least interest in GPM. The story could have been different, had Perrin positioned and problematized his method as being "better" than its rivals, something that $\mathrm{ABC}$ proponents would do forty years later.

\section{The Diffusion of $A B C$ in France}

ABC was initially popularized in the USA in the mid 1980s (Jones and Dugdale, 2002). It was then diffused gradually in many other countries throughout the 1990s (Bjornenak, 1997; Malmi, 1999). The first series of French inscriptions on ABC date back to the late 1980s (Lorino, 1989). This is the point at which we arbitrarily start to follow the actors.

\subsection{Importing and problematizing $A B C$}

Several actors - that would soon be tied by various links - contributed to ABC's importation to France, so it is hard to identify a single pioneer. Pierre Mévellec is professor at the University of Nantes. His first contact with ABC dates from a trip to the USA in the mid1980s. On his return to France, Mévellec began to try out ABC in a small industrial company. 
He reported on this experiment at the annual conference of the Association Française de Comptabilité $^{12}$. There, he met and exchanged ideas with, among others, Serge Evraert, professor at the University of Bordeaux. Both professors decided to set up other experiments in several companies. They then jointly published two articles recounting these experiments (Evraert and Mévellec, 1990, 1991). During the same period, Mévellec joined ECOSIP where he met Philippe Lorino ${ }^{13}$. In 1991, Mévellec published one of the first French books entirely dedicated to ABC (Mévellec, 1991).

Philippe Lorino, who was not yet a professor, discovered ABC by reading US articles and books on the subject. In the late 1980s, he was commissioned to modernize the management accounting system of a large French IT company, and started to implement ABC there. $\mathrm{He}$ took part in the creation of ECOSIP. This research group bound together a heterogeneous set of actors that contributed directly or indirectly to the early diffusion of $\mathrm{ABC}$ in France. Among its members were ABC adopters, spokespersons of the modernization of France's management tools, the Ministry of Research and Industry, consulting firms and academics. In 1990, Lorino became president of the Cost Management System group for CAM-I Europe. Parallel to this, he published two books (Lorino, 1989, 1991).

Michel Lebas, professor at HEC, discovered ABC during trips to the USA in the mid1980s and through his contacts with US academics. In 1986, he was among the few French to attend the first CAM-I conference in Europe. In 1991, he published a major article about ABC in the Revue Française de Comptabilité (RFC; Lebas, 1991) ${ }^{14}$.

This small number of actors can be considered, through their writings and experiments, as $\mathrm{ABC}$ pioneers in France. Their self-interest in promoting $\mathrm{ABC}$ is quite clear. On the one hand, as an innovative method, $\mathrm{ABC}$ was for academics a means of keeping their research, teaching

\footnotetext{
${ }^{12}$ The French academic accounting association, similar to the British (BAA) and American (AAA) ones. ${ }^{13}$ ECOSIP is a research group founded in 1988 and composed of companies and research labs. Its aim is to exchange information and experience on the topic of industrial economic evaluation.

${ }^{14}$ This French accounting review is a professional journal. There was no French academic journal specifically dedicated to accounting at that time.
} 
and consultancy activities going. Adopters such as Lorino saw $\mathrm{ABC}$ as a solution for renovating companies' cost management systems. Overall, $\mathrm{ABC}$ provided answers, at least in part, to the problems posed by the new industrial context of the 1980 s.

Indeed, looking back to the $1980 \mathrm{~s}$, at a period when $\mathrm{ABC}$ was rather less certain than a ready-made costing system, it is possible to unfold several similarities between the two "prehistories" of this innovation in France and in the US. In the "Harvard approach" used by ABC proponents to initially problematize and promote this method in the USA, the US industry was depicted as experiencing an unprecedented wave of new opportunities and threats such as the development of advanced manufacturing technologies and increasing international competition (Jones and Dugdale, 2002).

Using a similar problematization tactic, French ABC pioneers used existing inscriptions produced by other authors that diagnosed the difficulties facing French industry. Hence, Lorino (1991) presented $\mathrm{ABC}$ as an innovation meeting the requirements of the new industrial competition of the early 1990s, whereas Mévellec (1991) dedicated dozen of pages to describing the roots of management accounting's crisis (i.e. internal transformation of organizations, changes in the environment and modification of the demands on the information system).

In France, like in the USA, ABC was therefore problematized as a remedy for the crisis of management accounting, a way of rescuing national industries (and by the same token, defending the French nation). Hence, in the late 1980s, a few actors progressively imported $\mathrm{ABC}$ to France and started to form a fragile network. These pioneers played a major role in ABC's early diffusion, as they produced the first French inscriptions and initiated implementations in companies. All these actors had in common the way they first came across ABC: by interacting with the Harvard and/or CAM-I networks described by Jones and Dugdale (2002). 


\subsection{First-wave translations and the building of a fragile network}

When translating ABC into French, early promoters such as Lebas or Mévellec - as Kaplan and his allies did before them (Jones and Dugdale, 2002) - tried to make ABC an obligatory point of passage for companies coping with the difficulties they faced in the "new" industrial environment. As these pioneers all came across $\mathrm{ABC}$ through interactions with the Harvard and/or the CAM-I networks, their first inscriptions were to some extent influenced by these interactions. They dedicated large amounts of their writings to the method's costing aspects, among which the general architecture of the system (see Figure 1 below) and the translation/adaptation of specific concepts, such as "cost driver", required to operate it.

\section{Insert Figure 1 about here}

One important event following $\mathrm{ABC}$ 's importation and first-wave translation was the creation of a feature section specifically dedicated to management accounting in the $R F C$ journal. In the late 1980s, the French Ordre des Experts Comptables was concerned about the ability of its general accounting model to fit companies' management accounting needs ${ }^{15}$. The Ordre asked Lebas to participate in a management accounting research group called CEREDE. The aim of this group was to look for solutions addressing companies' management accounting needs (Lebas and Mévellec, 1992). Lebas persuaded the Ordre to create a feature dedicated to management accounting in the RFC. Lebas also asked Mévellec to share with him the responsibility of chief editor of the feature. They did so from 1991 to 1996. Thirty-five articles on ABC were published over this period.

For the ABC network, the accountant profession was a powerful potential ally, be it independent accountants (who could propose $\mathrm{ABC}$ consulting missions to their clients) or chief accountants in companies (who could convince their company to implement ABC). The

\footnotetext{
${ }^{15}$ This Ordre is only partly similar to the Orders of the chartered/certified accountants. In France, management accounting and financial accounting are not separated in terms of regulatory bodies. Hence, there is no specific management accountant regulatory body but only professional associations.
} 
aim was to make $\mathrm{ABC}$ an obligatory point of passage for the accountant profession if this latter wished to satisfy companies' new management accounting needs. Moreover, the work done by CEREDE members was to be used by the Ordre for renovating the management accounting section of its new upcoming version of the Plan Comptable. This was a superb opportunity to inscribe $\mathrm{ABC}$ into the new Plan Comptable, a powerful inscription that is known and used by all French accountants. This was also when Pierre-Laurent Bescos and Carla Mendoza, both professors at ESCP, joined the ABC network. They soon published the first book relating several ABC implementations in French companies (Bescos and Mendoza, 1994), a work that had also been commissioned by the Ordre.

In the end, the feature enabled French $\mathrm{ABC}$ pioneers to enlarge their network and to enroll a large number of allies whose articles they also published in the $R F C$ 's feature section (Alcouffe, 2004). From that point onwards, companies from the executive education industry began to show an interest in ABC. They asked Mévellec, Lebas, Lorino and Bescos to take part in the seminars and conferences they organized on the subject. At this point, ABC seemed to be on the road to "successful" diffusion. But this would be underestimating a major controversy...

\subsection{ABC vs. the Sections Homogènes: The Empire strikes back!}

A few months after its importation by a fragile network of pioneers, $\mathrm{ABC}$ faced a major controversy. This controversy concerned its innovative character in comparison with an older French method: the Sections Homogènes. Indeed, on its introduction in France, a large number of academics and practitioners saw in $\mathrm{ABC}$ solely a re-creation of the Sections Homogènes. $\mathrm{ABC}$ proponents were thus confronted with the very same anti-program Georges Perrin had faced forty years earlier (see Section 3).

The first anti-ABC inscriptions appeared in 1992-1993 and took the form of papers presented at the annual congresses of the Association Française de Comptabilité. These early 
inscriptions were soon taken on, developed and explicitly embodied in a widely diffused book written by Henri Bouquin (Bouquin, 1993). Bouquin is professor at the prestigious Paris Dauphine University and is one of France's major authors in the field of management accounting and control systems. The Sections Homogènes anti-program found in him a powerful spokesperson. Bouquin's arguments can be summarized in three points. First, ABC is not new: it is the US reinvention of the Sections Homogènes (Bouquin, 1993, p. 5). Second, ABC's technical qualities in terms of cost calculation are not superior (p. 8). Third, and more important, $\mathrm{ABC}$ 's answer to the question of management accounting's relevance is doubtful (p. 9). This last point is of importance because it was the relevance issue that would lead to the second wave of ABC's translations (see $\S 4.4$. below).

A second reason for which $\mathrm{ABC}$ was put into competition with the Sections Homogènes is the "double translation" issue. Being imported from a country using a different language (USA), ABC had to undergo a double translation in order to diffuse in France: translation in the sense of ANT, but also translation from English to French. These two processes are not independent: translation from one language to another is not neutral because different possibilities exist and translators make deliberate choices. In giving a French name to $\mathrm{ABC}$, various terms such as "comptabilité par activités" (i.e. accounting by activity), “comptabilité d'activités" (activity accounting) and “comptabilité à base d'activités” (activity-based accounting) were used simultaneously and/or sequentially. This diversity of names reflected the confusion about the meaning of the term "activite"” (activity) in French. As explained by Lebas (1994a), the terms "activity" and "function" are often mixed up, as are "activity" and "product" or "segment of activity". This confusion was due to translation from English to French but also to the fact that the first French $\mathrm{ABC}$ authors did not use any words other than "activite", a word with more than one meaning in French. 
This difficulty of operating a double translation was not only limited to the name "ABC" or to the "activity" concept. The concept of "cost driver" was also a source of problems for sometime. Indeed, the Sections Homogènes concept of unité d'œuvre is very close in meaning to that of cost driver ${ }^{16}$. Initially translated as "inducteur de coût" (a literal translation), the first French $\mathrm{ABC}$ authors attached the same meaning to the cost driver concept as to that of unité d'œuvre:

"The identification of an activity must go along with the definition of what causes this activity; it is this cause that will be taken as a cost driver. For example, the order reception activity has its origin in the number of orders received and not in the volume or price of goods received. Hence, it should be the number of orders received that should be taken as the cost driver of this activity." (Mévellec, 1990, p. 87)

Moreover, the confusion about the double translation of the cost driver concept (Alcouffe and Malleret, 2004) as well as its proximity with the Sections Homogènes concept of unité d'oeuvre led people to focus so much more on ABC's costing dimension than on the activity management one (ABM). This last point is of importance in the settlement of the controversy.

\subsection{Second-wave translations and the settlement of the controversy}

Facing a major controversy with the Sections Homogènes, ABC proponents could either give up the fight or not engage in it. However, they fought in a subtle manner. First, they recognized that it was a mistake to translate $\mathrm{ABC}$ essentially as a costing method (Lebas, 1994b). They held early US allies such as Kaplan responsible for this. Second, they admitted and appropriated for themselves the argument developed by counteractors that, when implemented and used "correctly", ABC and the Sections Homogènes gave similar results in terms of cost calculation. Third, and more important, French ABC proponents launched a new

\footnotetext{
${ }^{16}$ So close, in fact, that Lorino (1991) used "unité d'œuvre" as a French translation for "cost driver" in his first ABC model (see Figure 1).
} 
wave of translations. During this process, translations of $\mathrm{ABC}$ went from the description of a cost calculation method tout court to the elaboration of a new mode of management, even a new philosophy for some. This second wave of translations still drew on the writings of early US allies such as Cooper, Kaplan and Johnson, and was mainly based on the concepts of "process management" and "cross functionality":

"Before being a costing system, $\mathrm{ABC}$ is first and foremost a mode of modeling the functioning of organizations... Such an approach is a lot more ambitious than a simple cost calculation technique." (Mévellec, 1995, p. 38) "Instead of picturing a firm as a juxtaposition of responsibility centers... the firm becomes a network of processes or activities." (Lebas, 1994b, p. 46-47)

Although the impetus for this new translation was largely influenced by "global/US" ideas (i.e. those embodied in what is called "ABM"), the form that $A B C$ would take in the French setting also had some specific features, in response to the Sections Homogènes controversy. Indeed, at first hampered, $\mathrm{ABC}$ proponents used the trials they faced to translate this innovation into something more acceptable for its opponents. Hence, this second wave of $\mathrm{ABC}$ translations resulted in the settlement of the controversy with the Sections Homogènes method. This is best illustrated in the new writings of the most vocal (now former) ABC opponent. After having criticized ABC, Bouquin (1997) now saw in this innovation an act of renovating the language of accounting. In turn, this act of renovation could help the emergence of a new management control model that Bouquin was seeking. The second wave of translations made $\mathrm{ABC}$ an obligatory point of passage for Bouquin in his quest for a renovated model of management control. Acting formerly as a counteractor, Bouquin now became an ally and joined the $\mathrm{ABC}$ network.

At the same time, the Sections Homogènes lost another powerful ally: the French Plan Comptable. The latter had always been a pillar of the Sections Homogènes anti-program (see 
Section 3) by presenting it as the full costing reference method to French companies and accountants. Yet in 1999, the management accounting section of the new version of the Plan Comptable was abandoned. This was both a good and a bad event from the ABC network's standpoint: Good insofar as the Sections Homogènes had lost a powerful ally; and bad insofar as this former counteractor could not be enrolled as an ally into the $\mathrm{ABC}$ network. In the end, this event was also a failure to enroll the accountant profession into ABC's network.

\subsection{Bringing new allies on board and $A B C$ 's black-boxing}

As the controversy with the Sections Homogènes was being settled, the consulting industry expanded its $\mathrm{ABC}$ "business". Members of the network also created several small consulting firms specializing in ABC. In 1997-1998, the two most important publishers of ABC software opened offices in Paris. How can we explain the arrival of ABC-dedicated software publishers at this stage in the diffusion process? It seems that the second wave of $\mathrm{ABC}$ translations had played an important role here. For software publishers, the fact that $\mathrm{ABC}$ had initially been translated as a costing method tout court and had been put in competition with the Sections Homogènes had thus far been a major constraint:

"The French market has several specificities... one of them is the management accounting tradition which means that a number of companies already have a satisfactory costing system. This reduces ABC's impact and attractiveness..." (Interview with a manager of $\mathrm{ABC}$ Technologies)

But from the moment $\mathrm{ABC}$ was translated into $\mathrm{ABM}$, i.e. a new process-based mode of management, and new non-human actors such as TQM were enrolled into the network, the job of software publishers was made a lot more easier:

"The process and activity concepts broke through with such approaches as total quality management, ISO certifications, etc." (Interview with a manager of ABC Technologies) 
As a result, now translated into some kind of $\mathrm{ABM}, \mathrm{ABC}$ represented a business opportunity attractive enough for software publishers to decide to open offices in Paris. But when we look at the ABC actor-network, a type of ally was still missing: end-user adopters. Indeed, after the failed enrolment of accountants, this type of ally was still absent. Aware of this, $\mathrm{ABC}$ proponents, with consultants and software publishers at the vanguard, turned to management controllers.

Management controllers' tentative enrolment was performed through their professional association: the $D F C G$. This association sent to all its members a professional journal entitled Echanges and organized thematic conferences on a regular basis. Pierre-Laurent Bescos was one of the principal instigators of its enrolment. He was the first to publish an article in Echanges dealing with $\mathrm{ABC}$ (Bescos, 1995). In this article, Bescos presents $\mathrm{ABC}$ as the obligatory point of passage for management controllers to meet the new needs facing them in the economic context of the 1990s (the very same problematization arguments used earlier by pioneers to import ABC into France). Over the period 1995-2000, no less than 17 conferences on ABC were held by the DFCG throughout France (Alcouffe, 2004). Among the speakers were Pierre-Laurent Bescos and several representatives of major consulting firms and software publishers. Also, two-dozen articles were published in Echanges over the same period.

Following the enrolment of management controllers as $\mathrm{ABC}$ end-users, consultants and software publishers then worked together on hundreds of $\mathrm{ABC}$ implementations in French companies (Alcouffe, 2004):

"The diffusion boom in 1997 is not due to some fashion effect, it is due to the fact that $\mathrm{ABC}$ was made official thanks to the opening of $\mathrm{ABC}$ Technologies and Armstrong Laing's offices in Paris..." / “ABC's real diffusion began with the creation of dedicated software" / "one important factor on the French market is the arrival of Armstrong Laing 
and ABC Technologies" (Interviews with a consultant / an academic pioneer / another consultant)

This period can therefore be considered as a dramatic "take-off" for ABC in France. The initial actor-network composed of a few pioneers had developed into several ramifications, not wholly separate but nevertheless distinct. As the controversy with the Sections Homogènes ended, a large number of professors began to join the $\mathrm{ABC}$ network. These newly enrolled actors started research projects and began to publish in academic reviews. Research was no longer concerned with $\mathrm{ABC}$ itself but with various aspects of its implementation and use. Even though there was still no agreed norm, there seemed to be a consensus about the term "ABC". In other words, the ABC black box closed and the terms "activity", "process" and "cost driver" took the form of "hard facts". In the final analysis, the great majority of French management accounting textbooks now present $\mathrm{ABC}$ as a common full-costing method.

\section{Discussion}

What lessons can we draw from the comparison of the two symmetrical stories - one of "success", one of "failure" - of ABC and GPM diffusion in France? This paper contributes to the debate about accounting change and suggests four distinctive lessons.

Generally speaking, our work endorses the arguments put forward by alternative management accounting research on change, although we do not directly address the ontology of this concept as Quattrone and Hopper (2001) do. According to these arguments, change in accounting is neither necessarily linear nor foreseeable (Baxter and Chua, 2003). In our socioconstructivist vision, change is rather a drift of practices (Quattrone and Hopper, 2001) that move in time and space along the interactions of a multitude of actors. As both stories show, change in accounting is not pre-determined but made of several forward and backward moves 
and of rhetorical reformulations. As Quattrone (2004) suggests, it is actors' practices that construct the idea of stability and change. Members of the $\mathrm{ABC}$ network tried to construct the idea that their innovation constituted a change vis-à-vis existing French practices embodied in the Sections Homogènes. On the other hand, counteractors argued that ABC's principles were cast into a certain Historical stability. This controversy was settled once ABC was translated into another idea of change on the ground of new practices (i.e. process management and cross-functionality) and embodied into ABM.

Besides this contribution to the accounting change debate, it is possible to draw four original lessons based on the four moments that constitute translation, i.e. problematization, interessement, enrolment and mobilization.

First, problematization is not just technical but may also refer to such lofty ideals as the defense of the Nation (Jones and Dugdale, 2002). The solution proposed (the innovation) may even sound like a new enlightenment of managerial practices. But this depends on the actors' ability to enroll ideals that are not already embodied into other competing innovations (antiprograms) that have already achieved the status of black boxes. In the case of GPM, the ideals that Perrin tried to enroll were already part of (more) powerful networks supporting the Sections Homogènes and Direct Costing. However, in the 1980s, it was yet again possible to enroll these ideals as they were once again spotlighted by the diagnosis of the industrial crisis in western countries. The $\mathrm{ABC}$ network took advantage of this to enroll such ideals as the defense of the Nation, at the expense of the Sections Homogènes. At the same time, the GPM network tried to give a new impetus to its diffusion, not trying to enroll any ideals but by simply relying on a technical comparison with $\mathrm{ABC}$.

This phenomenon is partly similar to the one observed by Jones and Dugdale (2002). As in France, $\mathrm{ABC}$ was proposed in the USA as a solution to the problems encountered by manufacturing companies facing a new competitive environment. However, our two stories 
go further as they reflect a more complex situation. Three networks competed at different moments in time for the problematization of their innovation. This comparison brought to light exclusion phenomena. Whereas Direct Costing and the Sections Homogènes co-existed peacefully (Zimnovitch, 1997), GPM did not survive competition with these two. Yet such phenomena are temporary and reversible, as clearly shown by ABC's struggle with the Sections Homogènes. This makes the notions of accounting change, stability and progress even less definitive. Finally, this comparative study enabled us to take into account power relations between various innovations instead of considering them one by one as if they were diffusing in a vacuum (Quattrone and Hopper, 2005).

Second, various interessement modalities explicitly stand out in our two stories. Interessement can be commercial (an innovation to sell), political (a response to national challenges), editorial (a topic to publish on), intellectual (a concept to teach and to research) or career enhancing (a distinctive expertise for professional managers). Yet for a managerial innovation to "successfully" diffuse, it seems necessary to have a diversity of interessement modalities that combine and overlap so as to give one another mutual support as shown by the $\mathrm{ABC}$ story. The microcosm of interessement modalities must meet the macrocosm of society: commercial interessement alone is not sufficient for an innovation to diffuse, as shown by the GPM story. In the case of GPM, interessement modalities were in fact purely commercial and did not permit allies other than consulting firms to be enrolled. In the more recent renewal of interest for GPM, one can note the intellectual interest of some academics in this method. The only message Georges Perrin conveyed to the potential allies of his time was that GPM would be a source of consulting missions. He did not succeed in developing political interessement as explained in the previous point.

The case of $\mathrm{ABC}$ is more complex. This innovation was used by a handful of academics to "reform" the management accounting field in France: a field that had scarcely been called into 
question since 1947 (Lebas, 1994a). Promoters and opponents found in ABC an opportunity for confrontation. There was also, for consultants and software publishers, an obvious shared commercial interest in promoting the diffusion of this innovation. However, French consultants were also enrolled into the $\mathrm{ABC}$ network through intellectual interessement (some of them did their Ph.D. dissertations on this topic). Similarly, young academics saw in ABC a good subject for publication at a time where publication pressure became an inescapable "reality" for French academics.

Third, as Briers and Chua (2001) already mentioned, the question of characterizing "successful" and "not-successful" accounting change remains. Enrolment seems to be the key concept when addressing this issue. This question refers to the elaboration of an alternative to the positivist "diffusion rate" measure for assessing the success or failure of innovations. Our research leads us to propose an alternative perspective (rather than an alternative measure) to the concept of success/failure in itself, based on ANT concepts. Attention should not be focused on the concept of success/failure but on the description of the network that supports the innovation, i.e. the enrolment of human and non-human actors, allies and spokespersons. Success and failure are only rhetorical constructions of the network: the rule is not that, once the machine works, people will be convinced, but that "the machine will work when all the relevant people are convinced" (Latour, 1987, p. 10).

Network characteristics are the ever-evolving product of a series of translations that follow trials of strength. It is interesting to note that, of the two innovations we have studied, the one that did not diffuse is also the one that was supported by a single champion: GPM. Georges Perrin, on his own, did not succeed in promoting his method; on the contrary, ABC was supported by a variety of actors enrolled in its network. Following Briers and Chua (2001), we can notice that success and failure "is a fragile construction that turns on the strength of diverse ties tying together many heterogeneous elements". However, since faith is 
not a tangible criterion, we should try to assess the characteristics of the actor-networks that support the innovation, aside from the success/failure rhetoric produced by its members.

Fourth, this research explored how local controversies interfere with globalization and hamper the standardization/homogenization process of management accounting practices. Literature on globalization, as Baxter and Chua (2003) emphasize, is a fertile ground for alternative research because it encourages us to see management accounting as a set of practices that is deeply involved in complex processes of interpenetration between organizations and society. But little is known about the ways in which management accounting systems move in time and space. Does diffusion inevitably lead to the homogenization of management accounting practices (Granlund and Lukka, 1998)? How far does the local context offer resistance to these phenomena? How do local controversies, such as the one between $\mathrm{ABC}$ and the French Sections Homogènes method, affect practices?

From an ANT point of view, time/space movements and translations are linked. There cannot be movements (drifts) without some adaptation/translation and vice versa. Hence, any diffusion in time and space is a paradox as its outcome is both homogenization and heterogenization of practices. For example, our story about ABC showed that France and the USA used the same concepts called ABC and ABM even though they did not correspond exactly to the same practices. ABC's importation from the USA to France (a movement in time and space) gave rise to multiple double translations of its concepts (translation in the sense of ANT and from English to French). In turn, these multiple translations gave birth to specific practices (Mévellec, 1993). For its part, GPM remained uniform over time although changes in its name could lead us to believe that the method was evolving. Paradoxically, it was because GPM was not the subject of controversies - which would have driven the networks supporting it to adapt it - that it didn't diffuse and didn't become global. This leads us to raise the following question: can a method that remains uniform become global? 
Why is it a paradox to be homogeneous and heterogeneous at the same time? In fact, it may well be that the homogeneous/heterogeneous dichotomy is not appropriate. Like the previous dichotomies (success/failure and stability/change), the focus should be on the actornetwork and the practices of its members. It is the network's actors that construct the notions of homogenization and heterogenization through their practices. Some parts of the network are identical, whereas others are different, so that it is hard to tell whether the whole is heterogeneous or homogeneous. It is the rhetorical activity of the network's members that, in the end, enables us to decide.

Finally, this paper suggests some future avenues for research. Thus Baxter and Chua (2003, p. 109) ask whether the diffusion of an accounting practice may be achieved in a decontextualized way once it is incorporated into an IT package. Our case studies show complex situations where the local is able to resist the global, even when the innovations are carried in IT software. The role of non-human actors such as IT software could be the subject

of more in-depth research. For instance, to what extent do ERP tools lead to uniformisation of management control practices? We may also raise the question: what is the relevance of studying the diffusion of accounting technologies on a national level whenever heterogeneity is strong within one country? Likewise, what about adaptation and deployment of an innovation such as $\mathrm{ABC}$ within subsidiaries of a multinational company?

\section{Acknowledgements}

The authors would like to thank the two anonymous reviewers as well as participants at the EAA annual congresses in Gothenburg (May 2005) for their helpful comments. We are also especially indebted to David Cooper, David Emsley, Trevor Hopper and Robert Scapens for their insightful comments and suggestions on earlier versions of this paper. 


\section{References}

Alcouffe, S., (2004), La diffusion et l'adoption des innovations managériales en comptabilité et contrôle de gestion: le cas de l'ABC en France, Ph.D. Thesis, HEC, Paris.

Alcouffe, S., Malleret, V., (2004), Les fondements conceptuels de l'ABC “à la française”, Comptabilité - Contrôle - Audit, 10(2), 155-178.

Baxter, J., Chua, W.F., (2003), Alternative management accounting research - whence and whither, Accounting, Organizations and Society, 28, 97-126.

Berland T. and Boyns T. (2002), The development of budgetary control in France and Britain from 1920s to the 1960s: a comparison, European Accounting Review, 11(2), 329-356.

Bescos, P.-L., Mendoza, C., (1994), Le management de la performance, Editions Comptables Malesherbes, Paris.

Bescos, P.-L., (1995), Contrôle de gestion et management par les activités, Echanges, 113, 1012.

Bjørnenak, T., (1997), Diffusion and accounting: The case of ABC in Norway, Management Accounting Research, 8(1), 3-17.

Bloomfield, B.P., Vurdubakis, T., (1997), Visions of organization and organizations of vision: the representational practices of information systems development, Accounting, Organizations and Society, 22, 639-668.

Bloor, D., (1976), Knowledge and social imagery, Routledge, London.

Boltanski, L., (1982), Les cadres, la formation d'un groupe social, Paris, Les Editions de Minuit.

Bouquin, H., (1993), Comptabilité de gestion, Sirey, Paris.

Bouquin, H., (1997), Les fondements du contrôle de gestion, PUF, Que sais-je?, Paris. 
Briers, M., Chua, W.F., (2001), The role of actor-networks and boundary objects in management accounting change: a field study of an implementation of $\mathrm{ABC}$, Accounting, Organizations and Society, 26, 237-269.

Callon, M., (1986), Some elements of a sociology of translation: domestication of the scallops and the fishermen of St Brieuc Bay, in J. Law (ed.), Power, action and belief: a new sociology of knowledge?, Routledge and Kegan Paul, London.

Chua, W.F., (1995), Experts, networks and inscriptions in the fabrication of accounting images: a story of the representation of three public hospitals, Accounting, Organizations and Society, 20, 111-145.

Dhavale, D.G., (1996), Management Accounting. Issues in Cellular Manufacturing and Focused-Factory Systems, Montvale NJ, IMA Foundation for Applied Research.

DiMaggio, P.J., Powell, W.W., (1983), The iron cage revisited: Institutional isomorphism and collective rationality in organizational field, American Sociological Review, 48, 147-160.

Djelic, M.L., (1998), Exporting the American model; the postwar transformation of European business, New York, Oxford.

Ellwood, D.W., (1992), Rebuilding Europe; Western Europe, America and postwar reconstruction, New York, Longman.

Evraert, S., Mévellec, P., (1990), Calcul des coûts: il faut dépasser les méthodes traditionnelles, Revue Française de Gestion, march-april-may, 12-24.

Evraert, S., Mévellec, P., (1991), Les systèmes de coûts par activité. Réconcilier le calcul du coût des produits et le contrôle de gestion, Revue Française de Gestion, january-february, 91-102.

Ezzamel, M., (1994), Organizational change and accounting: understanding the budget system in its organizational context, Organization Studies, 15, 213-240. 
Granlund, M., Lukka, K., (1998), It's a small world of management accounting practices, Journal of Management Accounting Research, 10, 153-179.

Hopwood, A., (1987), The archaeology of accounting systems, Accounting, Organizations and Society, 12(3), 207-234.

Johnson, H.T., Kaplan, R.S., (1987), Relevance lost; the rise and fall of management accounting, Boston, Harvard Business School Press.

Jones, T.C., Dugdale, D., (2002), The ABC bandwagon and the juggernaut of modernity, Accounting, Organizations and Society, 27, 121-163.

Kipping, M., (1999), American consulting companies in Western Europe, 1920 to 1990: products, reputation and relationships, Business History Review, 73(2), 190-200.

Kipping, M., Bjarnar, O., (1998), The Americanisation of Europe business, London, Routledge.

Kuisel, R. F., (1981), Capitalism and the state in modern France: renovation and economic management in the twentieth century, Cambridge University Press.

Latour, B., (1987), Science in action, Harvard University Press, Cambridge, MA.

Latour, B., (1991), Technology is society made durable, in J. Law (Ed.), A sociology of monsters: Essays on power, technology and domination, Routledge, London.

Latour, B., (1996), Aramis; or the love of technology, Harvard University Press, Cambridge, MA.

Latour, B., (1999), On recalling ANT, in J. Law, \& J. Hassard (Eds.), Actor network theory and after, Blackwell Sociological Review, Oxford.

Latour, B., (2005), Reassembling the social. An introduction to Actor-Network Theory, Oxford University Press, Oxford.

Latour, B., Woolgar, S., (1979), Laboratory life: the construction of scientific facts, Sage, London. 
Lauzel, P., Bouquin, H., (1988), Comptabilité analytique, 5th edition, Sirey, Paris.

Law, J., Hassard, J., (1999), Actor network theory and after, Blackwell Publishing, Oxford.

Lebas, M., (1991), Comptabilité analytique basée sur les activités, analyse et gestion des activités, Revue Française de Comptabilité, 226, 47-63.

Lebas, M., (1994a), Managerial accounting in France. Overview of past tradition and current practice, European Accounting Review, 3(3), 471-487.

Lebas, M., (1994b), Du coût de revient au management par les activités, Revue Française de Comptabilité, 258, 45-51.

Lebas, M., Mévellec, P., (1992), A l'initiative du CEREDE, une nouvelle chronique sur la comptabilité de gestion, Revue Française de Comptabilité, 237, 60-61.

Lemarchand, Y., (2002), The military origins of the French management accounting model: a return to the mechanism of accounting change, Accounting History, 7(1), 23-57.

Levant, Y., de La Villarmois, O., (2001), Origine et développement d'une méthode de calcul des coûts: la méthode des Unités de Valeur Ajoutée, Comptabilité - Contrôle - Audit, $7(2), 45-66$.

Levant, Y., de La Villarmois, O., (2003), A propos des Libres commentaires du Professeur Mévellec (mai, 2002) et de l'article du professeur Meyssonnier (mai, 2003), Comptabilité - Contrôle - Audit, 9(1), 189-191.

Levant, Y., de La Villarmois, O., (2004), Georges Perrin and the GP cost calculation method: the story of a failure, Accounting Business and Financial History, 14(2), 151-181.

Lorino, P., (1989), L’économiste et le manager, La Découverte, Paris.

Lorino, P., (1991), Le contrôle de gestion stratégique, Dunod, Paris.

Lowe, A., (1997), The role of accounting in the process of health reform: providing a "black box" in the costing of blood products, Management Accounting Research, 8, 439-458. 
Lowe, A., (2000), The construction of a network at Health Waikato - The "towards clinical budgeting" project, Accounting, Auditing \& Accountability Journal, 13, 84-103.

Lowe, A., (2001a), Accounting information systems as knowledge-objects: some effects of objectualization, Management Accounting Research, 12, 75-100.

Lowe, A., (2001b), After ANT - An illustrative discussion of the implications for qualitative accounting case research, Accounting, Auditing \& Accountability Journal, 14, 327-351.

Lundblad, J.P., (2003), A review and critique of Rogers' diffusion of innovation theory as it applies to organizations, Organizational Development Journal, 21(4), 50-64.

Malmi, T., (1999), Activity-Based Costing diffusion across organizations: an exploratory empirical analysis of Finnish firms, Accounting, Organizations and Society, 24, 649-672.

Mévellec, P., (1990), Coût complet à base d'activités: une étude comparative, Revue Française de Comptabilité, 216, 83-91.

Mévellec, P., (1991), Outils de gestion: la pertinence retrouvée, Editions Comptables Malesherbes, Paris.

Mévellec, P., (1993) Plaidoyer pour une vision française de l'ABC, Revue Française de Comptabilité, 251, 36-44.

Mévellec, P., (1995), La comptabilité à base d'activités, Revue Fiduciaire Comptable, 212, $33-68$.

Mévellec, P., (2002), Libres commentaires à propos de l'article: Origine et développement d'une méthode de calcul des coûts: la méthode des unités de valeur ajoutée, Comptabilité - Contrôle - Audit, 8(1), 183-185.

Mouritsen, J., Larsen, H.T., Bukh, P.N.D., (2001), Intellectual capital and the "capable firm": Narrating, visualizing and numbering for managing knowledge, Accounting, Organizations and Society, 26(7\&8), 735-762. 
OECCA, (1952), La comptabilité mesure et facteur de productivité, Association Française pour l'Amélioration de la Productivité, Paris.

Ogden, S., (1997), Accounting for organizational performance: the construction of the customer in the privatized water industry, Accounting, Organizations and Society, 22, $529-556$.

Perrin, G., (1951), Bases doctrinales de la méthode GP et ses conséquences pratiques, Personal archives of Georges Perrin.

Perrin, G., (1955), Courrier du 11 février 1955 adressé au Président du Syndicat Cotonnier de l'Ouest, Personal archives of Georges Perrin.

Perrin, G., (1962), Prix de revient et contrôle de gestion par la méthode GP, Dunod, Paris.

Preston, A.M., Cooper, D.J., Coombs, R.W., (1992), Fabricating budgets: a study of the production of management budgeting in the National Health Service, Accounting, Organizations and Society, 17, 561-593.

Quattrone, P., (2004), Commenting on a commentary? Making methodological choices in accounting, Critical Perspectives on Accounting, 15, 232-247.

Quattrone, P., (2005), Reflections on the 'genesis of managerialism' and the related debate in (accounting) history: Diffusion vs. translation of accounting practices, $28^{\text {th }}$ EAA annual congress, Gothenburg, Sweden.

Quattrone, P., Hopper, T., (2001), What does organizational change mean? Speculations on a taken for granted category, Management Accounting Research, 12, 403-435.

Quattrone, P., Hopper, T., (2005), A ‘time-space odyssey’: management control systems in two multinationals organisations, Accounting, Organizations and Society, 30, 735-364.

Robson, K., (1992), Accounting numbers as "Inscriptions": action at a distance and the development of accounting, Accounting, Organizations and Society, 17, 685-708. 
Robson, K., (1994), Inflation accounting and action at a distance: the Sandilands episode, Accounting, Organizations and Society, 19, 45-82.

Rodrigues, L.H., Brady, G., (1992), Cost accounting and production control in a multiproduct environment. The Unit of Production Effort method, International Journal of Operations and Production Management, 12(10), 66-80.

Rogers, E.M., (1995), Diffusion of innovations, The Free Press, New York.

Serrières, X., (1969), La guerre ou la paix dans l'entreprise? Réflexions sur la participation, Etudes, january, 5-19.

Standish, E.M.P., (1990), Origins of the Plan Comptable Général: a study in cultural intrusion and reaction, Accounting and Business research, 20(80), 337-351.

Wolfe, R., (1994), Organizational innovation: review, critique and suggested research directions, Journal of Management Studies, 31(3), 405-431.

Zimnovitch, H., (1997), Les calculs du prix de revient dans la seconde industrialisation en France, Ph.D. Thesis, Poitiers University, France. 
Figure 1: First Translations of ABC Architectures by Lebas, Lorino and Mévellec

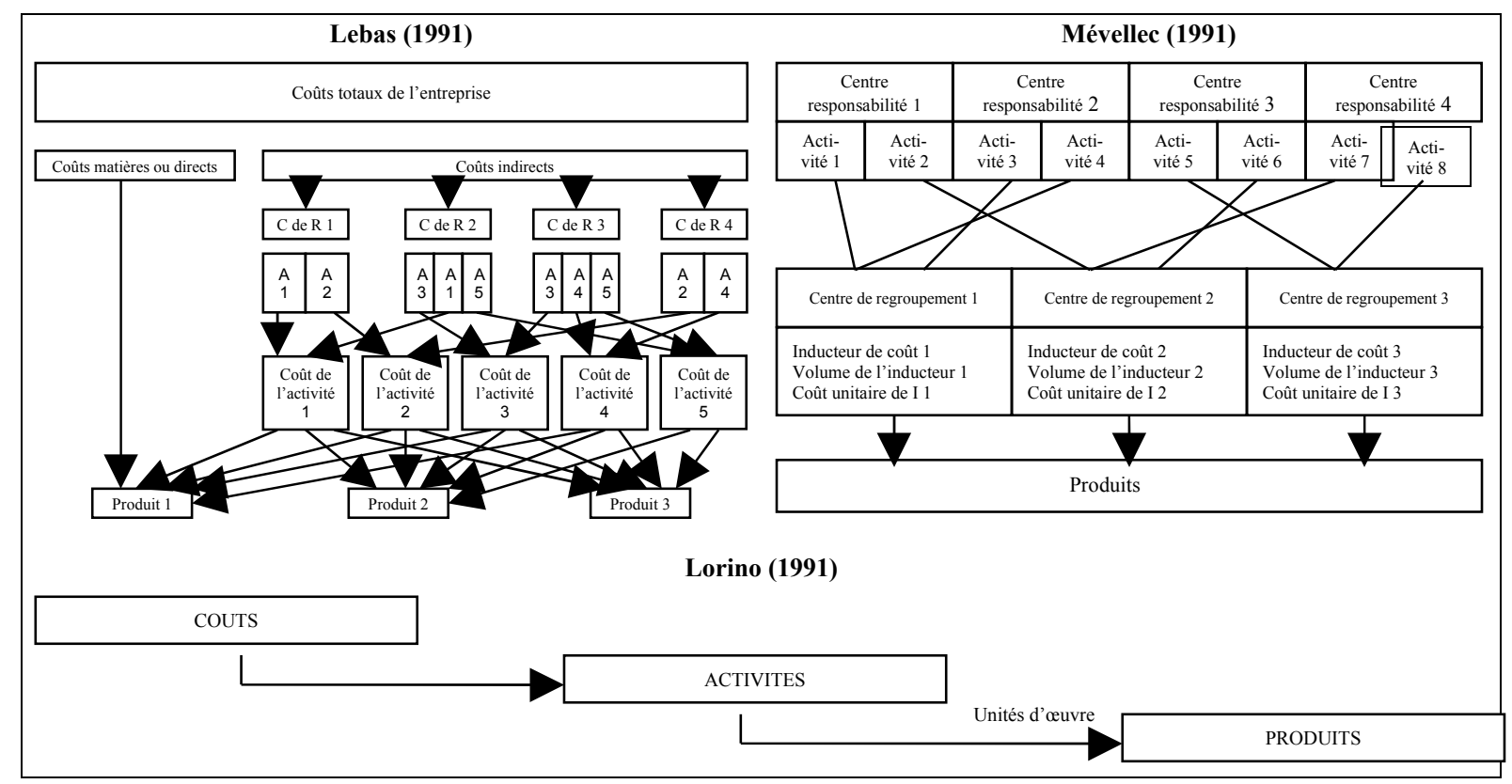

